\title{
NYLON ARTHROPLASTY IN RHEUMATOID AND OSTEO-ARTHRITIS*
}

\author{
BY \\ JOHN G. KUHNS and THEODORE A. POTTER \\ Boston, Mass., U.S.A.
}

We cannot foresee the time when early treatment of arthritis will prevent all articular damage and, consequently, all deformity about the joints (Hench and others, 1949). In spite of good nursing care and early splinting, occasionally severe injury to joints will occur. Without proper care, severe crippling is the common end-result. In chronic rheumatoid arthritis the greatest amount of crippling occurs in the lower extremity, and the knee joint shows the greatest disability. This begins with flexion deformity and progresses to subluxation, destruction of the articular surfaces, or ankylosis of the joint, Kuhns (1942).

The prevention and correction of these disabilities have always been serious problems, for when much damage has occurred, normal function is rarely regained. One of the most serious disabilities is ankylosis of the knee joint; while ankylosis in full extension does not interfere greatly with walking or standing, but is extremely awkward, and seriously disturbs rising and sitting. If both knees are stiff, it is often impossible for the patient to rise or dress himself without help.

Attempts have been made in the past to correct deformity and to produce motion in the knee joint stiffened by rheumatoid arthritis either by resection of the joint (Murphy, 1913) or by reshaping the articular surfaces and the interposition of fascia lata (Putti, 1920). In rheumatoid arthritis the tissues are defective, the bones are atrophied, the muscles are weak, and the fascia is thin, friable, and deficient in collagen, and rapidly wears away with use. Again, if adequate preparation and care have not been given to the patient an exacerbation in the arthritis may occur after operation.

Most of those who have reported upon arthroplasty of the knee have advised against its use in the presence of chronic arthritis (Samson, 1949), and our results up to 1940 had led us to a similar opinion. In twelve arthroplasties of the knee performed with the interposition of fascia lata, all soon became stiff again or had only a few degrees of painful motion of no practical value. The fascia lata soon disappeared and adhesions or bony ankylosis developed within the joint.

In our attempt to find a more durable substance for interposition between the articular surfaces after ankylosis from chronic arthritis, we asked the advice of the

* Read at the Annual Meeting of the American Rheumatism Association, San Francisco, Calif., June, 1950. 
Polaroid Corporation of Cambridge, Mass. They provided five types of thin plastic membrane: polythene, butacite, pliofilm, ethocel, and two types of nylon. Small pieces of each of these plastic membranes were inserted into the rectus sheath of white rats. When the rats were sacrificed in one month in the course of other experiments, the tissues about the inserted membrane were examined. Little irritation was observed in the rectus sheath from any of these plastics; but no irritation was seen about the nylon membrane. Small pieces of nylon were then attached to the denuded under surface of the patella in rabbits. Here, also, no inflammation was observed in the joint and the animals seemed to use the knee in a normal manner. Necropsy showed practically no inflammation about the nylon. After studying methods of attaching the nylon to the periosteum or bone, it was used in the formation of new knee joints in patients with quiescent arthritis.

Nylon is the trade name for a synthetic base for rayon. Its chief commercial use is in the manufacture of tough, fine threads which are used for fabrics. Nylon thread has been used in surgery for many years and a number of reports have mentioned its inertness in tissues. Nylon is tough, moderately elastic and resistant to moisture and chemicals (Ingraham and others, 1947), but since it melts with heat, nylon membrane cannot be sterilized in the usual manner. It is most easily sterilized by immersion for 12 hours in a cold solution of bichloride of mercury, 1 to 1,000 . For at least an hour before operation the nylon is soaked in sterile water or normal saline in order to remove as much bichloride as possible.

\section{Operative Procedure}

Our method of forming new knee joints is a simple one modified from that of Hass (1930). All the earlier students of this problem soon learned that intricate reconstruction of articular surfaces was a waste of time since the bone ends were greatly changed in shape by weight-bearing and by use. The knee joint is exposed by a long medial parapatellar incision. The patella is chiselled free from the femur, which, with the attached quadriceps tendon, is retracted laterally. The bony ankylosis between femur and tibia is chiselled away. The knee is then flexed. The lower end of the femur is fashioned into a rounded wedge transversely. A shallow groove is formed in the tibial plateau to fit the lower end of the femur. About one inch of the joint is resected in most instances, to permit unobstructed motion. The intercondylar notch is deepened for the patella. The patella is made thin and coin-like. All roughened areas are made smooth with a rasp. A single layer of nylon is sewed to the periosteum and bone of the femur covering all articular surfaces and the supra-patellar pouch. Pleats in the nylon are burned down smoothly with the electrocautery (Fig. 1).

In the postoperative care the leg is usually kept elevated upon pillows for $\mathbf{4 8}$ hours. Transfusions of one to two pints of blood are usually given as well as penicillin as prophylactic measures. The dressing is not changed for four or five days. Muscle-setting exercises are begun before the end of the first week after operation. Active exercises are begun after one week. Movement against gravity is begun as soon as the wound is healed. Weight-bearing with crutches and a plaster cylinder are begun in three weeks unless there is much bony atrophy. Resistance exercises (De Lorme and Watkins, 1948) are given to regain normal strength in the extensor muscles. Six months are usually required to regain normal strength and good function. 
A
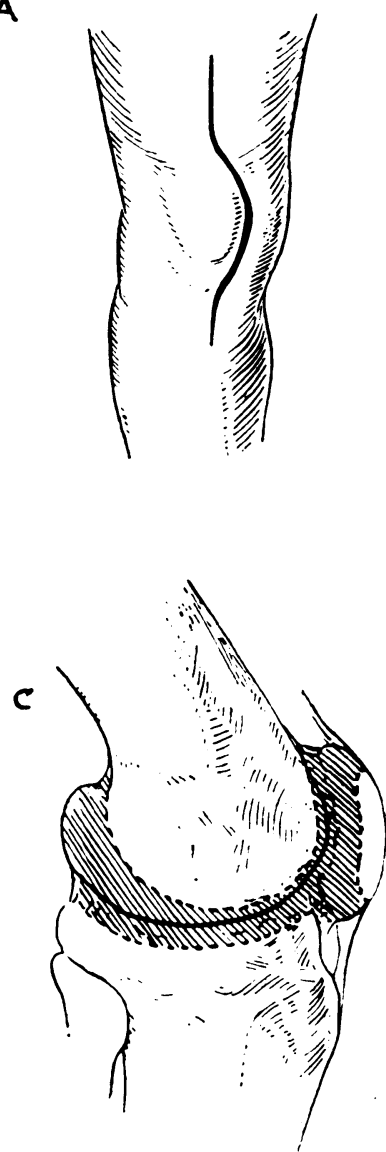

B

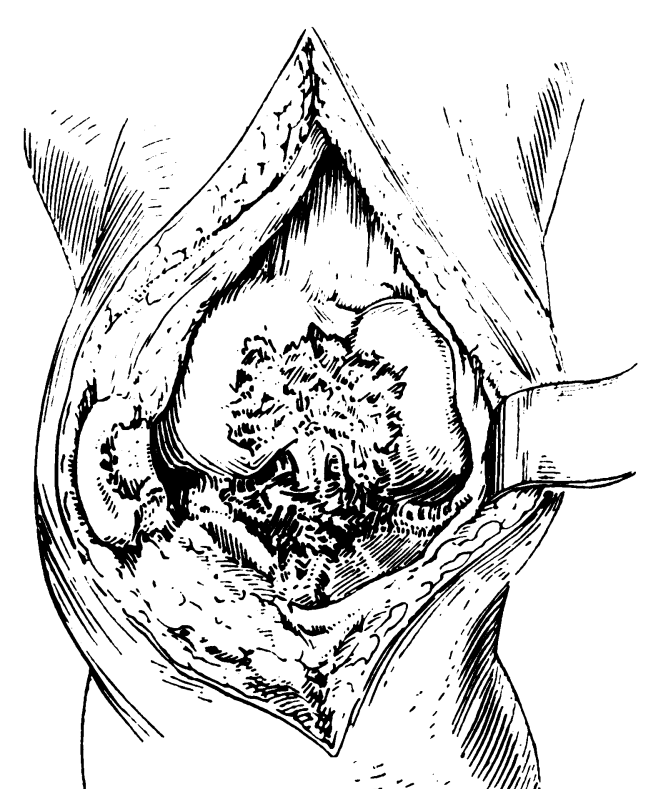

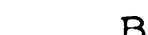

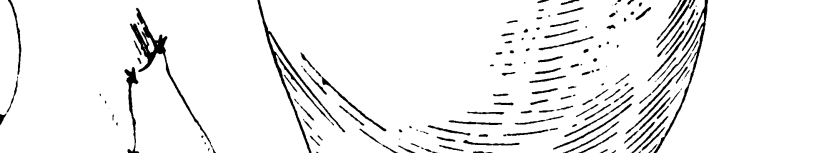

A. Incision.

FIG. 1.-Sketches of operative procedure.

B. Appearance of joint. The patella has been displaced.

C. Shaded area shows amount of bone removed.

D. Nylon attached to the periosteum at margins of femoral condyles.

\section{Results}

We have now employed this operation in thirty-three patients. Fourteen of them had bony ankylosis and nineteen had fibrous adhesions with destruction of the articular surfaces and limited painful motion in the joint. 
Bony Ankylosis.-The operations upon the patients with bony ankylosis are summarized in Table I. All had rheumatoid arthritis, except one who had a suppurative arthritis followed by bony ankylosis of the knee joint. In the first six patients the knees were ankylosed in extension and we lengthened the rectus femoris tendon in order to permit the knee to flex $90^{\circ}$. Further experience taught us that such lengthening was unnecessary and that adequate flexion of the knee could be obtained without it.

We do not know when an arthroplasty of the knee can be considered an endresult. Our first patient was operated upon six and a half years ago. It usually requires about six months for the patients to obtain good function and to become free from all pain; in many patients we have observed a steady gain both in strength and in motion for a much longer period. In this group with bony ankylosis all obtained a satisfactory range of painless motion, except two: in one of these a slough

TABLE I

BONY ANKYLOSIS

\begin{tabular}{|c|c|c|c|c|c|c|c|c|}
\hline \multicolumn{3}{|c|}{ Case } & \multirow{2}{*}{$\begin{array}{c}\text { Date } \\
\text { of } \\
\text { Operation }\end{array}$} & \multirow{2}{*}{ Diagnosis } & \multirow{2}{*}{ Knee } & \multirow{2}{*}{$\begin{array}{l}\text { Preoperative } \\
\text { Position }\end{array}$} & \multirow{2}{*}{$\begin{array}{l}\text { Postoperative } \\
\text { Motion }\end{array}$} & \multirow{2}{*}{ Remarks } \\
\hline No. & Sex & Age & & & & & & \\
\hline 1 & F. & 28 & Jan. ' '44 & Rheumatoid & Right & $170^{\circ}$ & $180-90^{\circ}$ & Quad. leng. \\
\hline 2 & M. & 30 & Oct. ' ' 44 & $\begin{array}{l}\text { Rheumatoid } \\
\text { Previous } \\
\text { arthroplasty }\end{array}$ & Right & $165^{\circ}$ & 0 & $\begin{array}{l}\text { Quadriceps } \\
\text { slough }\end{array}$ \\
\hline 3 & M. & 22 & Sept. ' 45 & $\begin{array}{l}\text { Rheumatoid } \\
\text { Previous } \\
\text { arthroplasty }\end{array}$ & Left & $160^{\circ}$ & $180-85^{\circ}$ & $\begin{array}{l}\text { Quadriceps } \\
\text { lengthening }\end{array}$ \\
\hline 4 & F. & 46 & Apr. '46 & Rheumatoid & Left & $170^{\circ}$ & $170-155^{\circ}$ & No pain \\
\hline 5 & F. & 30 & June ' 46 & Rheumatoid & Left & $160^{\circ}$ & $180-80^{\circ}$ & Quad. leng. \\
\hline 6 & F. & 22 & May '47 & Rheumatoid & Right & $175^{\circ}$ & $180-110^{\circ}$ & No pain \\
\hline 7 & M. & 20 & July '48 & Pyogenic & Right & $175^{\circ}$ & $175-170^{\circ}$ & $\begin{array}{l}\text { Re-Op. } 3 / 49 \\
180-135^{\circ} \\
\text { No pain }\end{array}$ \\
\hline 8 & F. & 24 & Sept. '48 & Rheumatoid & Left & $180^{\circ}$ & $180-130^{\circ}$ & $\begin{array}{l}\text { Quadriceps } \\
\text { Haemorrhage }\end{array}$ \\
\hline 9 & F. & 18 & Oct. ' '48 & Rheumatoid & Left & $150^{\circ}$ & $180-120^{\circ}$ & No pain \\
\hline 10 & F. & 47 & Oct. ' '49 & Rheumatoid & Right & $150^{\circ}$ & $180-100^{\circ}$ & No pain \\
\hline 11 & F. & 51 & Nov. '49 & Rheumatoid & $\overline{\text { Right }}$ & $95^{\circ}$ & $180-90^{\circ}$ & No pain \\
\hline 12 & F. & 54 & Dec. '49 & Rheumatoid & Left & $140^{\circ}$ & $180-100^{\circ}$ & No pain \\
\hline 13 & F. & 23 & Jan. ' 50 & Rheumatoid & Right & $180^{\circ}$ & $180-120^{\circ}$ & No pain \\
\hline 14 & F. & 30 & Mar. '50 & Rheumatoid & Left & $180^{\circ}$ & $180-140^{\circ}$ & No pain \\
\hline 15 & F. & 35 & May '50 & Rheumatoid & Left & $170^{\circ}$ & - & - \\
\hline
\end{tabular}


of the quadriceps muscle followed lengthening of the rectus femoris tendon; in the other extensive fibrous adhesions about the articular margins greatly restrict motion. We have now learned to avoid both these complications (Fig. $2 a$ and $b$ ).

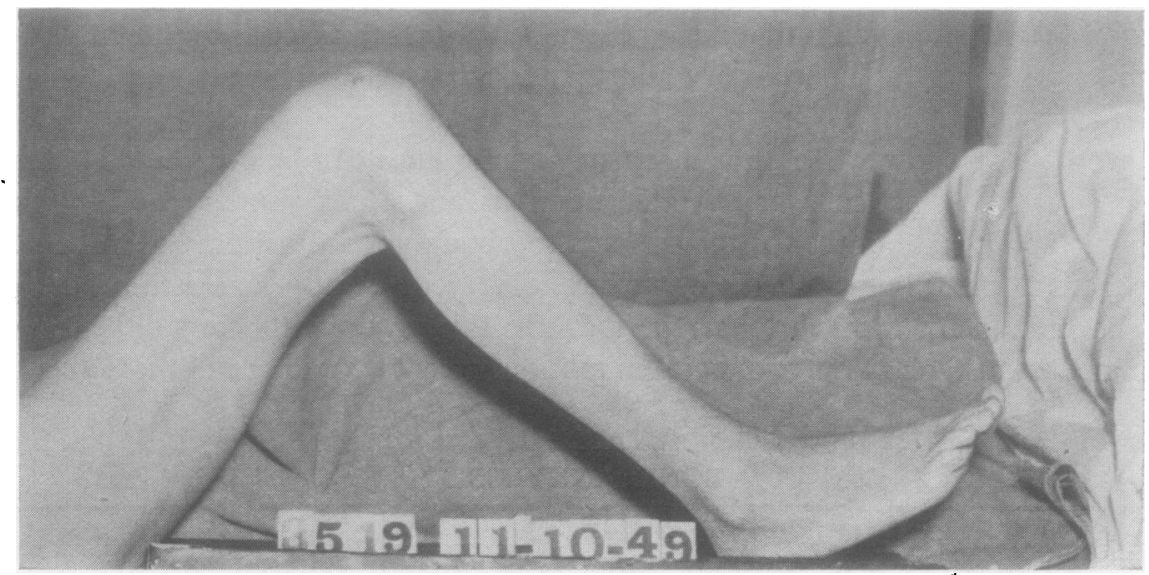

Fig. 2. (a).-Bony ankylosis of right knee of 20 years' duration.

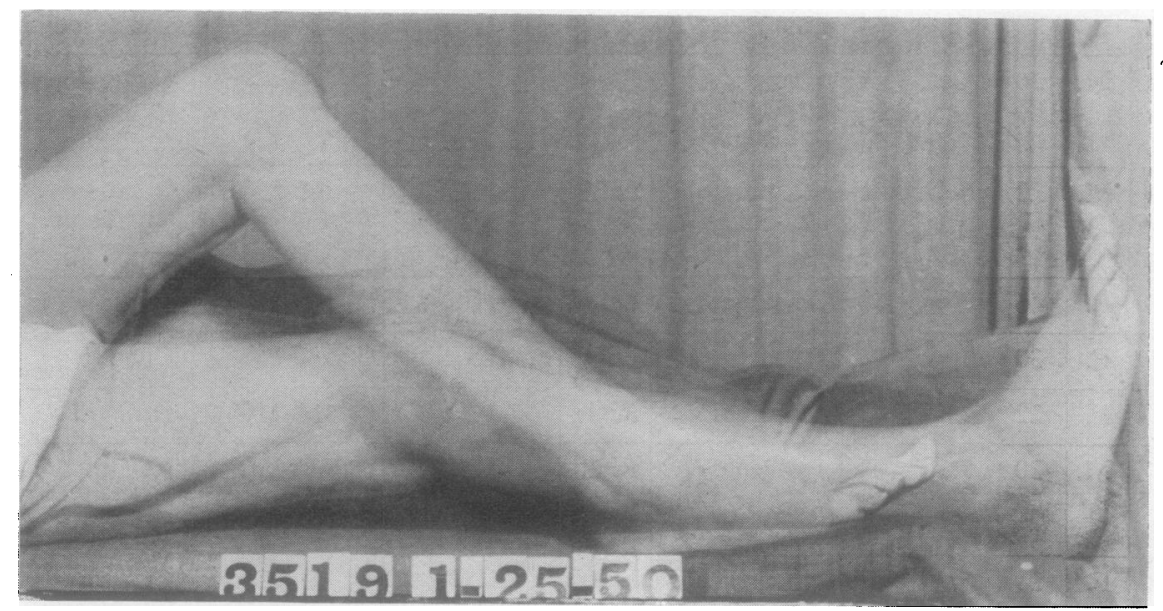

Fig. (b).-Same knee 2 months after nylon arthroplasty. Superimposed photographs show active range of flexion and extension.

Other Conditions.-Arthroplasties have been found of value in a number of conditions besides bony ankylosis. In many patients the end-result is destruction of the joint with severe pain on motion and on weight-bearing. This is found in both rheumatoid and osteo-arthritis. In such knees there are two procedures available, arthrodesis or arthroplasty. Practically all the patients requested that an attempt should be made to obtain motion before the knee joint was stiffened by operation. We have operated upon eighteen knee joints which were destroyed and painful but still retained a small range of motion. In these joints, markedly 


\section{Discussion}

Arthroplasty of the knee in chronic arthritis is always an operation of election. It does not produce a normal knee joint but usually results in a useful joint with a fairly wide range of painless motion. We believe that these joints, like those which have been operated upon with the interposition of fascia lata, will eventually wear out; but to date none of those we have treated have shown any functional deterioration.

There are no definite indications, but there are a few contraindications to arthroplasty. The chronic arthritis should be quiescent clinically. Local arthritic activity is sometimes confused with mechanical irritation of the joint. The other joints which have had arthritis should show no heat, swelling, or pain on motion. The general condition of the patient should be good in order to withstand an operation of this magnitude without danger. The patient should be co-operative and psychologically well adjusted. In children no arthroplasty should be performed until the epiphyses have closed, for operation upon an actively growing epiphysis will shorten the limb considerably. If there is much crippling there should be a definite plan of rehabilitation designed to correct the proximal joints before the more distal ones. There should be sufficient funds available for the necessary preoperative and postoperative care.

With our limited experience we feel that arthroplasty in chronic arthritis is indicated :

(1) In bony ankylosis of the knee when there is a fair range of motion in the hip joints. If the hips are stiff they should be mobilized before operation on the knee is contemplated. If both knees are ankylosed both can be operated upon, but at least a year should elapse between the two operations. In order to make walking possible, normal strength should be present in the first knee before the second knee is mobilized.

(2) In knee joints which have been severely damaged with resultant limited motion and painful weight-bearing. The articular damage is always found to be more severe at operation than the $x$-ray and the clinical examination would suggest. In a number of patien $s$ the operative procedure contemplated was synovectomy or removal of loose bodies and bony spurs, but in many instances extreme pannus formation, erosion and irregularity of the articular cartilages, and widespread adhesions with obliteration of the articular cavity forced us to construct a new joint in order to make articular function possible.

(3) In severe osteo-arthritis, whether primary or secondary, when there is extreme articular damage and no response to conservative therapy. Our experience both with debridement and with arthrodesis has been disappointing. With debridement alone, pain and increasing stiffness have soon recurred, as one would expect unless the underlying mechanical derangement had been corrected. Arthrodesis of the knee in osteoarthritis has soon led to similar pain in the ankle, hip, and low back. Relief of this degenerative process in any joint is dependent upon a nearly normal axis of motion in the joint and a normal line of weight-bearing which can be helped more effectively by arthroplasty than by any other known operative procedure.

In operations of this nature the postoperative period is most important, since motion depends upon the avoidance of complications and the early and persistent activity of the patient. The patient must begin motion or muscle-setting procedures 
proliferated synovial tissues were removed, the degenerated intra-articular ligaments were excised, and irregularities and bony overgrowth were made smooth (Table IJ). In osteo-arthritis our experience with articular debridement alone has been disappointing; extensive reshaping of the articular surfaces is always necessary. Here the interposition of some substance is necessary to prevent intra-articular adhesions. We have hesitated to perform an operation of this magnitude upon patients over 60 years of age. Those with severe osteo-arthritis of the knee upon whom an arthroplasty has been performed have now a wide range of painless motion, and we believe that the operation will have a wider application in severe osteo-arthritis.

TABLE II

FIBROUS ADHESIONS, DESTRUCTION OF JOINT

\begin{tabular}{|c|c|c|c|c|c|c|c|c|}
\hline \multirow[b]{2}{*}{ No. } & \multicolumn{2}{|l|}{ Case } & \multirow{2}{*}{ Date } & \multirow{2}{*}{ Diagnosis } & \multirow{2}{*}{ Knee } & \multirow{2}{*}{$\begin{array}{c}\text { Preoperative } \\
\text { Motion }\end{array}$} & \multirow{2}{*}{$\begin{array}{l}\text { Postoperative } \\
\text { Motion }\end{array}$} & \multirow{2}{*}{ Remarks } \\
\hline & Sex & Age & & & & & & \\
\hline 1 & F. & 54 & Oct. ' 45 & Rheumatoid & Right & $180-170^{\circ}$ & $170-100^{\circ}$ & No pain \\
\hline 2 & M. & 42 & July ' '47 & Rheumatoid & Left & $150-130^{\circ}$ & $170-110^{\circ}$ & Temporary sinus \\
\hline 3 & M. & 64 & Feb. ' 48 & Rheumatoid & Left & $180-170^{\circ}$ & $180-120^{\circ}$ & Slight pain \\
\hline 4 & F. & 53 & Mar. '48 & Rheumatoid & Right & $180-100^{\circ}$ & $180-75^{\circ}$ & No pain \\
\hline 5 & F. & 16 & May '48 & Rheumatoid & Right & $160-150^{\circ}$ & $175-85^{\circ}$ & No pain \\
\hline 6 & M. & 28 & Dec. ' 48 & Pyogenic & Right & $170-160^{\circ}$ & $180-140^{\circ}$ & Pain \\
\hline 7 & M. & 47 & Jan. ' '49 & Rheumatoid & Right & $165-95^{\circ}$ & $180-85^{\circ}$ & No pain \\
\hline 8 & M. & 54 & Feb. '49 & Rheumatoid & Left & $160-130^{\circ}$ & $180-95^{\circ}$ & No pain \\
\hline 9 & F. & 54 & Apr. '49 & $\begin{array}{l}\text { Osteo- } \\
\text { arthritis }\end{array}$ & Left & $170-95^{\circ}$ & $180-80^{\circ}$ & No pain \\
\hline 10 & F. & 51 & May '49 & Rheumatoid & Left & $155-130^{\circ}$ & $180-110^{\circ}$ & No pain \\
\hline 11 & M. & 48 & Sept. '49 & Rheumatoid & Left & $170-100^{\circ}$ & $180-110^{\circ}$ & No pain \\
\hline 12 & F. & 48 & Nov. ' 49 & $\begin{array}{l}\text { Osteo- } \\
\text { arthritis }\end{array}$ & Left & $170-155^{\circ}$ & $180-90^{\circ}$ & No pain \\
\hline 13 & M. & 44 & Dec. ' 49 & $\begin{array}{l}\text { Osteo- } \\
\text { arthritis }\end{array}$ & Right & $170-95^{\circ}$ & $180-90^{\circ}$ & $\begin{array}{l}\text { Nylon loosened } \\
\text { Slight pain }\end{array}$ \\
\hline 14 & F. & 40 & Jan. ' 50 & Rheumatoid & Right & $170-155^{\circ}$ & $180-100^{\circ}$ & No pain \\
\hline 15 & F. & 49 & Jan. ' 50 & Rheumatoid & Left & $165-120^{\circ}$ & $180-110^{\circ}$ & No pain \\
\hline 16 & $\mathrm{~F}$. & 55 & Feb. ' 50 & $\begin{array}{l}\text { Osteo- } \\
\text { arthritis }\end{array}$ & Right & $160-135^{\circ}$ & $180-90^{\circ}$ & Slight pain \\
\hline 17 & F. & 28 & Mar. '50 & Rheumatoid & Left & $150-110^{\circ}$ & $180-130^{\circ}$ & Slight pain \\
\hline 18 & M. & 42 & May '50 & Rheumatoid & Right & $155-100^{\circ}$ & Procedure no & t yet complete \\
\hline 19 & F. & 40 & May '50 & Rheumatoid & Left & $185-160^{\circ}$ & & , \\
\hline 20 & F. & 40 & May '50 & Rheumatoid & Left & $185-90^{\circ}$ & & ," \\
\hline
\end{tabular}


within a few days, and active and resistance exercises of increasing strenuousness must be performed after wound-healing to secure good motion and normal strength. In a few patients normal strength and good function have gradually come after a year and a half, but we do not advocate such slow convalescence; adhesions and muscular stiffness can develop too readily.

The desideratum after arthroplasty of the knee has changed little in the last 50 years: it is a stable, painless knee with about $60^{\circ}$ of motion. In a recent review, Speed and Trout (1949) stated that $70^{\circ}$ of motion made for the greatest endurance and stability, but many of our patients have over $90^{\circ}$ of motion and all of them are stable and painless. The greater range of motion, we believe, has resulted from the vigorous use of the newer physiotherapy techniques, particularly resistance exercises. Stability is chiefly the result of sparing the collateral ligaments and developing the musculature about the knee.

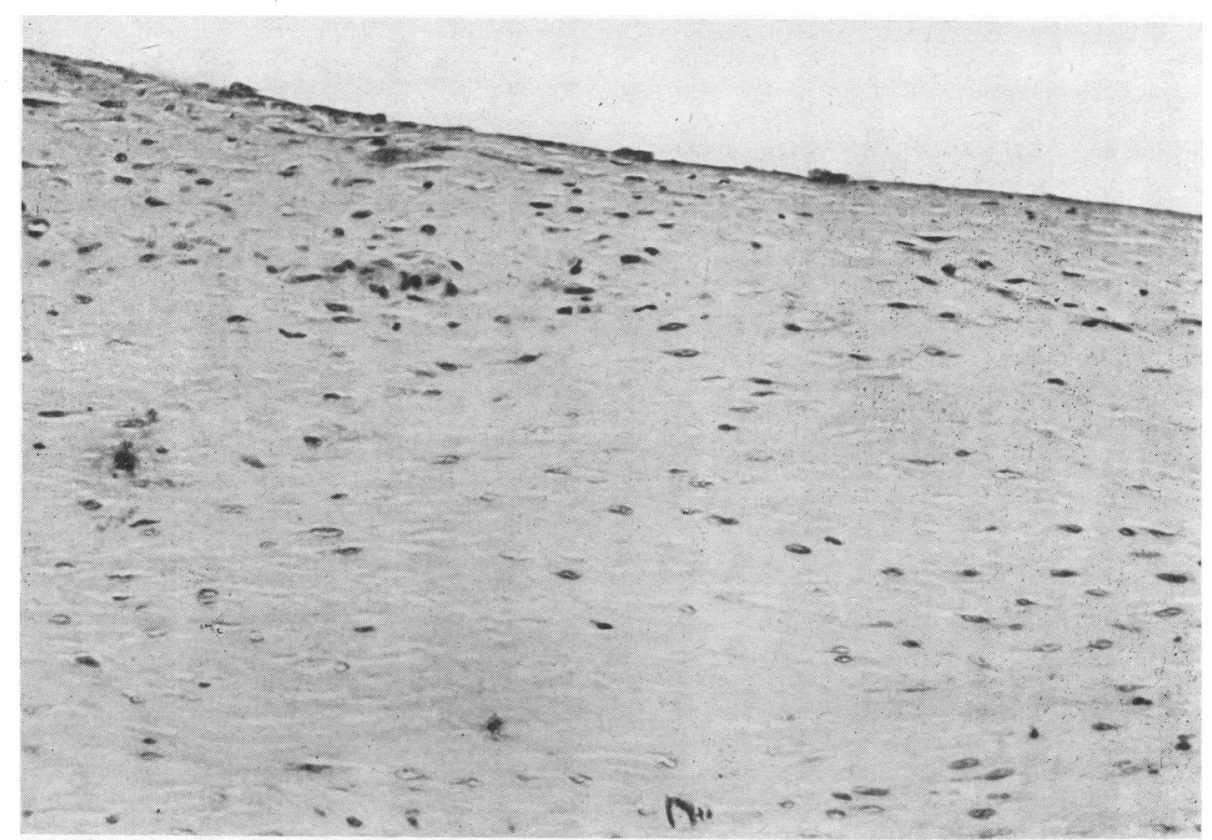

FIG. 3.-Tissue on femoral condyle beneath nylon membrane. There is no reaction to the nylon, and fibrous tissue forms a flattened layer beneath it.

The changes which occur in knees after nylon arthroplasty have been observed in $x$ rays and by re-operation in three patients. The changes are similar to those reported by Campbell after fascial arthroplasty, but adhesions are rare after nylon (Fig. 3). There is little postoperative effusion. After a few weeks the aspirated fluid resembles normal joint fluid. After walking in the presence of osseous atrophy, a little flattening occurs in the lower end of the femur, but as far as can be determined this does not interfere with the range of motion. In about four months the moving articular surfaces under the nylon become covered with a firm layer of 
fibrous tissue which resembles fibrocartilage. The soft tissues about the nylon undergo mild proliferation, but there is no definite inflammation. If the nylon becomes detached (this occurred in two patients), the symptoms of articular derangement and osseous and fibrous-tissue proliferation recur. No changes are observable after six months.

\section{Summary}

In patients with bony ankylosis or severe articular damage in chronic arthritis a useful range of painless motion can usually be obtained by arthroplasty with nylon membrane.

To date we have observed no reaction to the nylon membrane.

A firm layer of fibrous tissue develops under the nylon.

Careful postoperative attention is required to prevent complication and early active motion is essential to the success of this procedure.

\section{REFERENCES}

De Lorme, T. L., and Watkins, A. L. (1948). Arch. phys. Med., 29, 263.

Hass, J. (1930). Arch. klin. Chir., 160, 693.

Hench, P. S., Kendall, E. C., Slocumb, C. H., and Polley, H. F. (1949). Annals of the Rheumatic Diseases, 8, 97.

Ingraham, F. D., Alexander, E., and Matson, D. D. (1947). New Engl. J. Med., 236, 362, 402.

Kuhns, J. G. (1942). Ibid., 227, 975.

Murphy, J. B. (1913). Ann. Surg., 57, 593.

Putti, V. (1920). J. orthop. Surg., 2, 530.

Samson, J. E. (1949). J. Bone Jt Surg., 31-в, 50.

Speed, J. S., and Trout, P. C. (1949). Ibid., 31-B, 53.

\section{Discussion}

Dr. Philip LewIN (Chicago, Ill.): This is very interesting material. Duncan McKeever started using cellophane, and we began using nylon in 1943 at the Mayo General Hospital. Be sure to differentiate nylon sheeting from nylon fabric. This material is sheeting, and it works.

We reported on some of our work at the 6th Service Command Conference in 1944. We put nylon sheeting into skulls to replace the dura, and after eight or ten weeks it could be removed, washed, sterilized, and used over again. There was no reaction by the host tissues nor any reaction by the material upon the host tissues. We used it round tendons, nerves, and blood vessels. It is very interesting that you can seal it by a warm haemostat. If you have the haemostat warm enough, you can pinch it and seal it, just as little popcorn bags are sealed. When you put it round a structure such as a tendon and have a little sticking out, you can seal it with a couple of snaps so that sutures need not be used.

I hope, in closing the discussion, Dr. Kuhns will tell us how he secures it to the bone, because it is so difficult to attach this material by suture.

DR. KunNs: The cellophane was originally 0.003 in., but now they are making it 0.006 in. thick. Both materials work equally well, although the 0.003 -in. material is a little more elastic and easier to handle. It is secured from the Plastics Division of DuPont, and it costs $\$ 3.83$ per pound. One pound comes one foot wide and about three yards long. It will do a great many operations.

It is sutured either to the periosteum or to the bone. In two patients we did not fasten the nylon securely to the periosteum or to the bone, and it started to roll and gave us the same symptoms as internal derangement or torn cartilage. In those two patients we simply left it in place for 5 months and then removed it. 
Arthroplastie au Nylon dans l'Arthrite Rhumatismale

et dans l'Ostéo-arthrite

\section{RÉSUMÉ}

Dans des cas d'ankylose osseuse ou de lésion articulaire grave due à l'arthrite chronique on obtient généralement un mouvement indolore et d'amplitude utile après l'arthroplastie avec une membrane de nylon.

Jusqu'à présent nous n'avons pas observé de réactions dues à la membrane de nylon. .

Une couche compacte de tissu fibreux se développe sous cette membrane.

Un traitement post-opératoire soigneux est nécessaire pour éviter des complications et le mouvement actif précoce est essentiel pour que ce procédé réussisse.

\section{Artroplastia con Nylon en la Artritis Reumatoide y en \\ la Osteo-artritis}

\section{RESUMEN}

En casos de anquilosis ósea o de lesión articular debida a la artritis crónica grave se puede obtener generalmente movimientos sin dolor de amplitud útil por medio de artroplastia con una membrana de nylon.

Hasta ahora no hemos observado reacciones debidas a la membrana de nylon.

Una capa firme de tejido fibroso se desarrolla debajo de esta membrana.

Para evitar complicaciones hay que tratar a los enfermos con mucho cuidado y el movimiento activo temprano es preciso para el éxito del procedimiento. 